\title{
Effectiveness of vegetative filter strips in abating fecal coliform based on modified soil and water assessment tool
}

\author{
J. Bai ${ }^{1} \cdot$ Z. Shen ${ }^{1} \cdot$ T. Yan $^{1}$
}

Received: 28 September 2015/Revised: 9 April 2016/Accepted: 3 May 2016/Published online: 17 May 2016

(C) Islamic Azad University (IAU) 2016

\begin{abstract}
Pathogenic bacteria are a serious public health concern. Exposure to these microorganisms can result in illnesses or even death. Therefore, it is important to control pathogenic bacteria sources, transport mechanisms and fate. Best management practices proved to be very effective in the control of non-point source pollution. In this study, the soil and water assessment tool (SWAT) was modified and used to simulate the fecal coliform in Chao River of Miyun Reservoir watershed, China. The model was then used to explore the effectiveness of vegetative filter strips (VFS) in reducing fecal coliform abundance throughout the watershed. The water temperature equation within the SWAT was modified to align the model more closely with the characteristics of the study area and generate a more accurate simulation. The DAFS ratio $(20,50$, 80,120 and 150) and $\mathrm{DF}_{\text {con }}(0.25,0.4,0.6$ and 0.75$)$ parameters were considered for VFS to see their effects on removal efficiency. The results show that calibration and validation results for fecal coliform and flow can be accepted. Different values for DAFS ${ }_{\text {ratio }}$ and $\mathrm{DF}_{\text {con }}$ have great influence on VFS. Increasing values resulted in a decrease in the removal efficiency of VFS.
\end{abstract}

Keywords Hydrologic model - Miyun Reservoir watershed - Water quality - Watershed management

Z. Shen

zyshen@bnu.edu.cn

1 State Key Laboratory of Water Environment Simulation, School of Environment, Beijing Normal University, Beijing 100875, China

\section{Introduction}

Microorganisms found in non-point source pollution are a serious threat to human health. Harmful microbial pathogens can be spread through drinking water and other water systems, such as recreational water and aquaculture water. It is reported that approximately four billion cases of diarrhea cause 2.2 million deaths each year and 200 million people in the world are infected with schistosomiasis, of whom 20 million suffer severe consequences (WHO/UNICEF 2000). Changes in bacterial populations can directly reflect the characteristics of the habitat in which they are found. Therefore, monitoring and control of bacteria have been given increased attention in recent years. The application of manure in agricultural fields is a substantial threat to surface waters (Hyer and Moyer 2003). Research shows that the abundance of pathogenic microorganisms is increased in water bodies after a heavy rainfall. Therefore, controlling the transport mechanisms of pathogenic microorganisms especially after a storm is an important way to protect water quality.

The soil and water assessment tool (SWAT) model has been widely used in the study of bacteria. At present, studies using the model to simulate bacteria abundance and movement can be divided into the following two types: the application of the model and the specific use for the simulation. Application of the model generally includes the following aspects: a variety of models are applied to simulate bacteria (Moore et al. 1989; Benham et al. 2006; Frey et al. 2013), modifications for the existing model are researched (Kim et al. 2010; Cho et al. 2012), and a comparative study between different models is performed (Benham et al. 2006). Simulations for the model are divided into the following three categories: tracking sources of bacteria, conducting research on the impacts of multiple types of bacteria (Frey et al. 2013), and simulating the impacts of management measures (Parajuli et al. 2008). 
The SWAT model has been widely applied in the study of bacteria (Benham et al. 2006; Coffey et al. 2010; Frey et al. 2013). Past research identified that the SWAT model was limited in its ability to simulate bacteria abundance and transport; therefore, additional research was performed to improve the model. Cho et al. (2012) found that solar radiation is one of the most influencing factors in the fate of fecal coliform by assessing fecal coliform contamination in the Wachusett Reservoir watershed with a modified SWAT. Kim et al. (2010) added a bacteria transport subroutine to SWAT model to evaluate the Escherichia coli. Baffaut and Sadeghi (2010) indicated that the simulation process of bacteria may need to be revisited after reviewing several cases in which the SWAT model was used to simulate bacteria. The values of the evaluation indices $R^{2}$ and $E_{\mathrm{NS}}$ used in their study were lower than the generally acceptable range identified in present SWAT-based bacteria simulation studies (Baffaut and Benson 2009; Baffaut and Sadeghi 2010; Frey et al. 2013), which was related to many factors, including runoff, sediment, temperature and even nutrient content. Other scholars believe that the existence of shortcomings in the SWAT simulation process for bacteria may lead to low calibration and validation results (Baffaut and Sadeghi 2010). This study aims to identify the major problems in the SWAT model and uses the Chao River of Miyun Reservoir watershed as a case study to modify the SWAT model and improve the calibration results to obtain a more accurate simulation of bacteria.

Best management practices (BMPs) are the primary method used to control non-point source pollution and improve water quality. BMPs can be divided into source control techniques, process control techniques and terminal control techniques, according to different classifications. Research shows that different types of BMPs used in the control of nutrients, sediment, bacteria, pesticides and other pollutants have achieved positive results (Maringanti et al. 2008; Parajuli et al. 2008). However, not all BMPs can be used to remove pathogenic microorganisms. Vegetated filter strips (VFS) are recommended as one of the BMPs to prevent nutrients, manure-borne microorganisms and other contaminants from reaching surface water resources (Parajuli et al. 2008; Lewis et al. 2010; Fox et al. 2011).

VFS has proven to be effective in the removal of pathogenic microorganisms (Entry et al. 2000; Cardoso et al. 2012). At present, study of the removal of pathogenic microorganisms using VFS is focused on plot scale scenarios and model simulations. Research shows that many factors affect the removal efficiency of VFS, including type of vegetation used, strip length and width, and slope of the strip (Parajuli et al. 2008). The economics and optimization of VFS placement are the focus of current study (Shen et al. 2013).
The SWAT model not only simulates the fate and transport of nutrients and pathogens but also simulates management measures. At present, the application of VFS in the SWAT model is primarily associated with the removal of nutrients and bacteria. Existing studies mainly focus on the efficiency of bacteria removal using different VFS widths in the SWAT model. Parajuli et al. (2008) found out that 15-m lengths of VFS reasonably reduced fecal bacteria concentrations in the watershed when the SWAT model was applied to the removal of fecal coliform and sediment. This indicates that the parameters used to describe VFS in the SWAT model are an important consideration. The drainage area to VFS area ratio

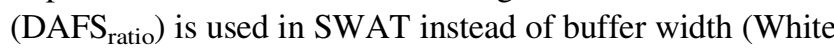
and Arnold 2009). However, little research has been performed correlating $\mathrm{DAFS}_{\text {ratio }}$ with bacteria removal efficiency.

In this paper, a modified SWAT model was used to simulate flow and fecal coliform in the Chao River of Miyun Reservoir watershed, China. The water temperature equation of the SWAT was modified to align the model more closely with the characteristics of the study area. The DAFS ratio $(20$, 50, 80, 120 and 150) and the fraction of the Hydrologic Response Unit (HRU in SWAT model) which drains to the most concentrated $10 \%$ of the VFS area defined as $\mathrm{DF}_{\text {con }}$ $(0.25,0.4,0.6$ and 0.75$)$ were considered for VFS to explore their effects on bacteria removal efficiency. The primary objectives of this research were (1) to modify the SWAT model to obtain more accurate results and in combination with other researchers studying bacterial model modifications make the simulation more complete; (2) to investigate the influence of different parameter values on the bacteria removal efficiency of VFS based on the VFS module of SWAT. The study area is the Chao River of Miyun Reservoir watershed, China. The fecal coliform samples were collected in 2013 .

\section{Materials and methods}

\section{Watershed and data}

The Chao River is located between North China Plain and eastern Inner Mongolia Axis with an area of $6155 \mathrm{~km}^{2}$ (Fig. 1). The research area and Bai River are two main tributaries to the Miyun Reservoir, which is located in the northeast of Beijing. The Municipality of Beijing consists of the city of Beijing together with several rural counties that surround it. The Miyun Reservoir is located in the rural counties of Beijing. The Miyun Reservoir is the most important drinking water source for Beijing. Approximately, $60 \%$ of the research area is covered by mountain. The major land use types are: forest $(50.90 \%)$, pasture $(25.45 \%)$ and agricultural land $(19.39 \%)$. The climate belongs to 
Fig. 1 Location of the study watershed and the hydrological sites

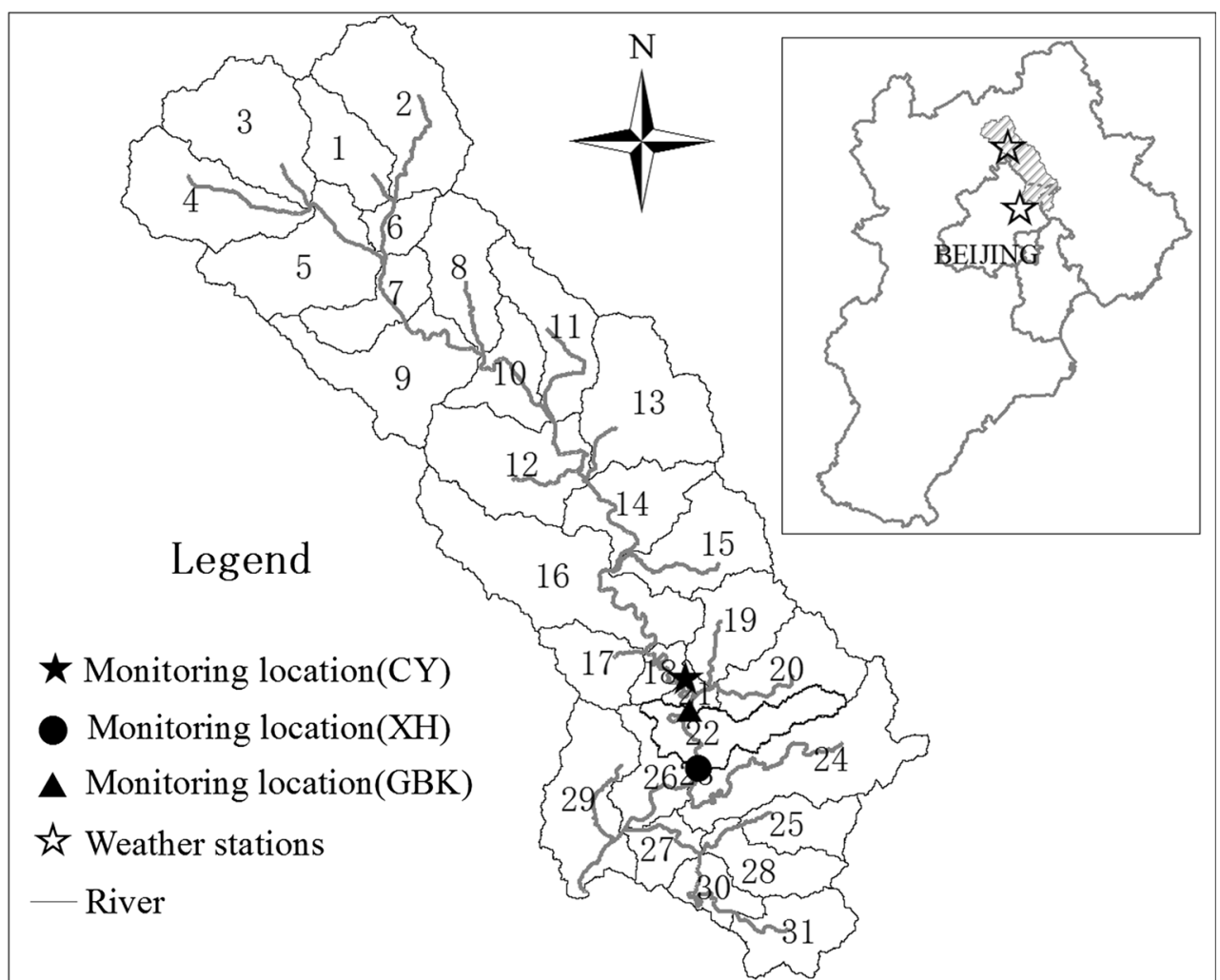

continental monsoon climate, precipitation of the Chao River more concentrated in the flood season, and the precipitation ranges from 261.4 to $750.0 \mathrm{~mm}$ per year (Wang et al. 2012).

The flow was calibrated and validated in Xihui (XH) and Guibeikou (GBK) from 2006 to 2010, and fecal coliform presence was calibrated and validated at three sites (CY, GBK and XH) in 2013. There are 22 rainfall stations and two weather stations in the watershed. The key data needed for this study were obtained from the following organizations:

(a) DEM: The National Geomatics Center of China.

(b) Land use: Institute of Geographical Sciences and Natural Resources Research, Chinese Academy of Science.

(c) Soil properties: Institute of Soil Science, Chinese Academy of Science.

(d) Weather data: China Meteorological Administration.

(e) Hydrology: Hydrological yearbook.

(f) Water quality: Fecal coliform samples were collected and measured at three sampling sites (CY, GBK and XH).

\section{Fecal coliform source characterization}

Classification of bacterial origin is very important and is primarily based on watershed characteristics. Current research classifies bacterial origins in the following categories: livestock, human, wildlife, grazing operations, manure applications and failing septic systems (Table 1). A region's size and location greatly influence the number and type of bacterial sources. For example, Table 1 identifies Little Cove Creek watershed as a small watershed with only one bacterial source. There is an obvious difference between the planting structures, livestock breeding practices and other land management practices in China and other countries. As a result, the sources of bacteria are also different. Sources of bacteria can also be related to the seasons. Bacteria source tracking performed by Benham et al. (2006) indicated that the contribution of animal manure on fecal pollution in summer was much higher than in winter. In the present study, identified differences in bacterial concentrations may greatly influence the bacterial content of the watershed. Bougeard et al. (2011) set the fecal bacteria concentration as $8.96 \times 10^{5} \mathrm{E}$. coli/g in the manure, while Parajuli et al. (2008) set a concentration of fecal coliform in the manure as $13 \times 10^{10} \mathrm{cfu} /$ day/AU (wet-weight-basis). In this study, the source of fecal coliform mainly considers the following source (Table 2), which presents the concentrations of fecal coliform from related research. As the watershed area is large, diversity of wild animal species is very rich. The primary wild animal species are listed in Table 2. In this study, sheep, cattle and duck were considered grazing animals, as identified through field investigations and a literature review. 
Table 1 Summary of the source classification of bacteria in application of SWAT model

\begin{tabular}{|c|c|c|c|c|c|}
\hline & $\begin{array}{l}\text { Shoal Creek } \\
\text { watershed }^{\mathrm{a}}\end{array}$ & $\begin{array}{l}\text { Little Cove Creek } \\
\text { watershed }^{\text {b }}\end{array}$ & $\begin{array}{l}\text { Upper Wakarusa } \\
\text { watershed }^{\mathrm{c}}\end{array}$ & Payne River watershed ${ }^{\mathrm{d}}$ & Sac River watershed ${ }^{\mathrm{e}}$ \\
\hline Area & $367 \mathrm{~km}^{2}$ & $68 \mathrm{~km}^{2}$ & $950 \mathrm{~km}^{2}$ & $178 \mathrm{~km}^{2}$ & $726 \mathrm{~km}^{2}$ \\
\hline \multirow[t]{4}{*}{ Source } & $\begin{array}{l}\text { Septic tanks and } \\
\text { illegal connections }\end{array}$ & - & Failing septic systems & Septic system & $\begin{array}{l}\text { Septic tanks, permitted } \\
\text { and facilities storm } \\
\text { runoff from urban areas }\end{array}$ \\
\hline & Poultry litter & - & Livestock & Manure and fertilizer & Livestock \\
\hline & Wildlife & - & Wildlife & Wildlife & Wildlife \\
\hline & Grazing cattle & Grazing operation & - & - & Horses \\
\hline Country & USA & USA & USA & Canada & USA \\
\hline Bacteria types & Fecal bacteria & E. coli & Fecal bacteria & $\begin{array}{l}\text { Cryptosporidium, } \\
\text { Salmonella, } \\
\text { Giardia Campylobacter, } \\
\text { fecal coliform, E. coli }\end{array}$ & Fecal coliform \\
\hline
\end{tabular}

${ }^{\mathrm{a}}$ Benham et al. (2006), ${ }^{\mathrm{b}}$ Kim et al. (2010), ${ }^{\mathrm{c}}$ Parajuli et al. (2008), ${ }^{\mathrm{d}}$ Frey et al. (2013), ${ }^{\mathrm{e}}$ Baffaut (2006)

Table 2 Sources of fecal coliform in the Chao River watershed

\begin{tabular}{|c|c|c|}
\hline Source & Typical sources & $\begin{array}{l}\text { Bacteria Production } \\
\text { Information }\end{array}$ \\
\hline Fertilization & $\begin{array}{l}\text { People and livestock } \\
\text { manure }\end{array}$ & $\begin{array}{l}\text { Parajuli et al. (2008), Bougeard } \\
\text { et al. (2011), ASAE (2000) }\end{array}$ \\
\hline \multirow[t]{5}{*}{$\begin{array}{l}\text { Wild } \\
\text { animal }\end{array}$} & Mongolian Sky Lark & $\begin{array}{l}\text { Moyer and Hyer (2003), } \\
\text { Middleton and Ambrose } \\
\text { (2005), ASAE (2000) }\end{array}$ \\
\hline & Lark & $\begin{array}{l}\text { Moyer and Hyer (2003), } \\
\text { Middleton and Ambrose } \\
\text { (2005), ASAE (2000) }\end{array}$ \\
\hline & Ring necked pheasant & $\begin{array}{l}\text { ASAE (2000), Moyer and Hyer } \\
\text { (2003) }\end{array}$ \\
\hline & Shelduck & $\begin{array}{l}\text { ASAE (2000), Moyer and Hyer } \\
\text { (2003) }\end{array}$ \\
\hline & The magpie duck & $\begin{array}{l}\text { ASAE (2000), Moyer and Hyer } \\
\text { (2003) }\end{array}$ \\
\hline \multirow[t]{3}{*}{ Grazing } & Sheep & $\begin{array}{l}\text { ASAE (2000), Moyer and Hyer } \\
\text { (2003) }\end{array}$ \\
\hline & Cattle & $\begin{array}{l}\text { ASAE (2000), Moyer and Hyer } \\
\text { (2003) }\end{array}$ \\
\hline & Duck & $\begin{array}{l}\text { ASAE (2000), Moyer and Hyer } \\
\text { (2003) }\end{array}$ \\
\hline $\begin{array}{l}\text { Point } \\
\text { source }\end{array}$ & $\begin{array}{c}\text { Urban wastewater } \\
\text { treatment plant } \\
\text { discharge water }\end{array}$ & $\begin{array}{l}\text { Zheng and Zhou (2013), Yang } \\
\text { et al. (2008); cities sewage } \\
\text { treatment plant pollutant } \\
\text { discharge standard in China }\end{array}$ \\
\hline
\end{tabular}

\section{The modified SWAT model}

The SWAT is one of the most widely used distributed models and simulates long-term flow, sediment and nutrient losses in rural watersheds. The SWAT model is suitable for complicated large watersheds with different soil types and land use, and by setting the catchment area threshold, the basin can be divided into sub-basins and these sub-basins are further discretized into HRUs. Non-persistent pathogens and persistent pathogens are the two different populations of enteric organisms that can be simulated by the SWAT model. The microbial survival and transport sub-model was first added in SWAT 2000 and was modified in the 2005 and 2009 versions. Many scholars have used the SWAT model to simulate pathogenic microorganisms (Parajuli et al. 2008; Cho et al. 2012; Frey et al. 2013).

The existing SWAT model is based on the experience and procedures of foreign countries and may not apply as well in response to the actual condition of this watershed. Water temperature data were used during the water quality simulation; however, due to the untimely determination, the equation proposed by the Stefan and Preud'Homme (1993) was used in the SWAT model to calculate the daily average temperature, where $T_{\text {water }}$ is the water temperature in ${ }^{\circ} \mathrm{C} ; \bar{T}_{\mathrm{av}}$ is the day's temperature in ${ }^{\circ} \mathrm{C}$.

$T_{\text {water }}=5.0+0.75 \bar{T}_{\text {av }}$

The water temperature equation was given by Stefan and Preud'Homme (1993) after calculating water temperatures for the tributaries to the Mississippi River in the USA. There are great differences between the Mississippi River watershed and the Miyun Reservoir watershed, with respect to both climatic conditions and geographical location. Therefore, this research will focus on the actual conditions of this watershed, and the water temperature formula will be recalculated to align the model more closely with the watershed, increasing the reliability of results during the calibration and validation processes.

The daily average temperature data of the Fengning station (2006-2009) in the Chao River watershed and daily water data of the Dage hydrologic station (2006-2009) are analyzed in this study. The Fengning station and Dage hydrological station are located in the upper reaches of Chao River watershed closely.

The indices of $R^{2}$ and $S_{\mathrm{p}}$ (Pilgrim et al. 1998) were used to calculate the equation's efficiency. Generally, $R^{2}=1$ and $S_{\mathrm{p}}=0$ denote the best fit equation. The ratio $S_{\mathrm{p}} / S_{\mathrm{e}}$ should be close to 0 and $R^{2}$ close to 1 in order for an equation to be a good fit. The equations are as follows: 
$R^{2}=1-\frac{S_{\mathrm{p}}^{2}}{S_{\mathrm{e}}^{2}}$

$S_{\mathrm{p}}=\sqrt{\frac{\sum_{i=1}^{n}\left(y_{i}-x_{i}\right)^{2}}{n-1}}$

$S_{\mathrm{e}}=\sqrt{\frac{\sum_{i=1}^{n}\left(y_{i}-\bar{y}\right)^{2}}{n-1}}$

$\bar{y}=\frac{\sum_{i=1}^{n} y_{i}}{n}$

where $S_{\mathrm{p}}$ is the standard error of the prediction value, $y_{i}$ is the measured value of water temperature, $x_{i}$ is the water temperature calculated by the temperature equation. By calculating water temperature and air temperature of this watershed, the new equation is:

$T_{\text {water }}=4.57+0.42 \bar{T}_{\mathrm{av}}$

The values of $R^{2}$ and $S_{\mathrm{p}}$ were 0.87 and 1.91 , respectively. Pilgrim et al. (1998) analyzed the relationship between water temperature and air temperature using daily, weekly, monthly and mean annual temperatures in the state of Minnesota. The ranges of $R^{2}$ and $S_{\mathrm{p}}$ were $0.133-0.991$ and $0.21-4.86$. Therefore, the conclusions of this study conform to standard statistical requirements.

Comparing (1) and (6), the intercept of (1) is 5, and the intercept of (6) is 4.57 . This is not a large gap; however, the slope of (1) is 0.75 , and the slope of (6) is 0.42 , which is an obvious difference. Therefore, when the temperature is high, the values of the two equations are different. When the temperature is $30^{\circ} \mathrm{C}$, the gap between the two equations is approximately $10{ }^{\circ} \mathrm{C}$. Temperature played an important role in the process of simulating bacteria; therefore, changes in water temperature may have an important impact on bacterial simulation.

\section{The VFS module of SWAT}

The VFS module in the SWAT 2009 model is used to simulate the removal of pollutants from the water in agricultural and urban regions. VFS were implemented at the HRU level with three parameters: $\mathrm{DAFS}_{\text {ratio }}, \mathrm{DF}_{\text {con }}$ and $\mathrm{CF}_{\text {frac }}$. DAFS $\mathrm{S}_{\text {ratio }}$ is the ratio of drainage area to VFS area, and $\mathrm{CF}_{\text {frac }}$ is the fraction of the flow through the most heavily loaded $10 \%$ of the VFS which is fully channelized. The fraction of the HRU which drains to the most concentrated $10 \%$ of the VFS area is defined as $\mathrm{DF}_{\text {con }}$. The related formulas can refer to White and Arnold (2009). The $\mathrm{DAFS}_{\text {ratio }}$ and $\mathrm{DF}_{\text {con }}$ are the most important parameters affecting removal efficiency compared to the $\mathrm{CF}_{\text {frac }}$. Hence, a large number of SWAT simulations were performed to evaluate the effects of DAFS ${ }_{\text {ratio }}$ and $\mathrm{DF}_{\text {con }}$ on
VFS effectiveness. However, few similar studies exist for bacteria. In this study, the coefficient of determination $\left(R^{2}\right)$ and the Nash-Sutcliffe efficiency $\left(E_{\mathrm{NS}}\right)$ were used to evaluate the performance of the model (Shen et al. 2013).

\section{Sensitivity analysis and calibration of hydrologic parameters}

Based on the actual conditions within the research area, the Chao River watershed was divided into 31 sub-basins, with $\mathrm{XH}$ selected as the outlet in the SWAT model. Obtaining optimum parameters for the hydrological models through calibration and validation was a very important process. The SWAT Calibration and Uncertainty Programs (SWAT-CUP) were used to calibrate the sensitive parameters and calibrate and validate the SWAT model in this paper (Abbaspour 2011). The SWATCUP method was selected because of its consideration of uncertainties and its high calibration efficiency (Shen et al. 2014). Table 3 summarizes the bacterial sensitivity parameter values from previous studies. In Table 3 , the value of BACTKDQ (the soil partitioning coefficient in surface runoff) is generally set to 175 , while THBACT (temperature adjustment factor for bacteria) is 1.07 in the watershed. WDLPS and WDPS represent the die-off factors for less persistent and persistent bacteria adsorbed by soil particles at $20^{\circ} \mathrm{C}$, respectively, both of which are lower than the values of WDLPQ and WDPQ, which represent the die-off factors for less persistent and persistent bacteria in soil solution at $20^{\circ} \mathrm{C}$. Study of the application of the SWAT model in simulating bacteria reflects that a reasonable value for THBACT is 1.07 . BACTKDQ influences the number of organisms transported by surface runoff. The recommended value for this variable is 175 .

The parameters sensitivity analysis result showed that the sensitivities of the two parameters (THBACT and BACTKDQ) are not very high in this paper; therefore, the values of the two parameters were set at 1.07 and 175. BACT_SWF can be specified as the fraction of manure containing organisms.

Table 3 Summary of bacterial parameter values in different studies

\begin{tabular}{|c|c|c|c|c|c|}
\hline & $\begin{array}{l}\text { Wachusett } \\
\text { Reservoir }^{\mathrm{a}}\end{array}$ & $\begin{array}{l}\text { Daoulas } \\
\text { estuary }^{b}\end{array}$ & $\begin{array}{l}\text { Little } \\
\text { Cove } \\
\text { Creek }^{\mathrm{c}}\end{array}$ & $\begin{array}{l}\text { Upper } \\
\text { Wakarusa } \\
\text { watershed }^{\mathrm{d}}\end{array}$ & $\begin{array}{l}\text { Fergus } \\
\text { catchment }\end{array}$ \\
\hline BACTKDQ & 166.14 & 90 & 175 & 175 & 175 \\
\hline BACT_SWF & 0.61 & 1 & 0.97 & - & - \\
\hline THBACT & - & 1.070 & - & 1.07 & 1.07 \\
\hline WDLPQ & - & 2.01 & - & - & - \\
\hline WDLPS & - & 0.023 & - & - & - \\
\hline WDPQ & - & - & - & 0.4 & - \\
\hline WDPS & - & - & - & 0.04 & - \\
\hline
\end{tabular}

${ }^{\mathrm{a}}$ Cho et al. (2012), ${ }^{\mathrm{b}}$ Bougeard et al. (2011), ${ }^{\mathrm{c}}$ Kim et al. (2010), ${ }^{\mathrm{d}}$ Parajuli et al. (2007, 2009), ${ }^{\text {e }}$ Coffey et al. (2010) 
Related research indicates that the value of BACT_SWF is different in different stages of the animal's growth. Referencing relevant studies, as outlined in Table 3 and the actual conditions of this area, the value of the BACT_SWF was set at 1 . WDLPQ and WDLPS had the highest sensitivity of all of the parameters. The values of these two parameters were set at 0.54 and 0.016 determined by the SWAT-CUP model.

\section{Results and discussion}

\section{Results of the calibration and validation}

Flow calibration and validation results are shown in Table 4. Flow was calibrated and validated at two sites (XH and GBK). The calibration period ran from 2006 to 2008, and the validation period ran from 2009 to 2010. The index values for calibration and validation at GBK and $\mathrm{XH}$ were no significantly different, because these two sites are relatively close geographically. The calibration and validation results for flow at the two sites are acceptable. Fecal coliform was calibrated and validated at three sites $(\mathrm{XH}$, GBK and CY). Generally, $E_{\mathrm{NS}}=0.5$ is recommended as a lower limit; evaluation values were summarized using the SWAT model for bacterial simulation research and shown in Table 5. $E_{\mathrm{NS}}$ values during calibration and validation ranged from -6 to 0.63 . In some watersheds, the results were very good; in other watersheds, the results are difficult to accept. In addition to the Shoal Creek watershed, the calibration results of other watersheds were $<0.5$. The differences in calibration results mainly resulted from the

Table 4 Model performance indicators of flow

\begin{tabular}{llllll}
\hline Name & \multicolumn{2}{l}{ Calibration } & & \multicolumn{2}{l}{ Validation } \\
\cline { 2 - 3 } \cline { 5 - 6 } & $R^{2}$ & $E_{\mathrm{NS}}$ & & $R^{2}$ & $E_{\mathrm{NS}}$ \\
\hline $\begin{array}{l}\text { XH } \\
\text { Flow }\end{array}$ & 0.72 & 0.49 & 0.78 & 0.61 \\
$\begin{array}{c}\text { GBK } \\
\text { Flow }\end{array}$ & 0.67 & 0.42 & 0.74 & 0.64 \\
\hline
\end{tabular}

Table 6 Results of calibration and validation of fecal coliform

\begin{tabular}{llllr}
\hline Name & Period & Sites & $R^{2}$ & \multicolumn{1}{c}{$E_{\mathrm{NS}}$} \\
\hline The no-modified SWAT model & Calibration & CY & 0.00 & -1.38 \\
& & GBK & 0.38 & 0.27 \\
& Validation & XH & 0.58 & 0.47 \\
The modified SWAT model & Calibration & CY & 0.11 & -0.20 \\
& & GBK & 0.34 & 0.19 \\
& Validation & XH & 0.69 & 0.46 \\
\hline
\end{tabular}

characteristics of the watershed, including land use, soil, runoff, sediment and so on (Coffey et al. 2010; Cho et al. 2012; Frey et al. 2013). In this respect, the results of this study are basically identical to other researchers' results. Therefore, so the $E_{\mathrm{NS}}$ of fecal coliform was acceptable during the calibration and validation period. Calibration and validation results of fecal coliform were better in this study compared with other similar studies.

\section{The results of the modified model}

The fecal coliform results of calibration are shown in Table 6. The value of $E_{\mathrm{NS}}$ was -0.20 at $\mathrm{CY}$ in the modified model, which was greatly improved compared with the -1.38 value obtained in the unmodified model. The results form GBK and XH are basically the same in both models. In the modified model, the model was recalibrated to change parameters. The parameters were adjusted, the sensitivity of WDLPQ, BACTKDQ and THBACT was not high in the SWAT-CUP model, but the sensitivity of WDLPS was very high; additionally, an increase or decrease of 0.01 units for this variable had a strong impact on the results. In the modified model, the value of WDLPS was 0.020 compared with 0.016 in the original model in the SWAT-CUP model. Thus, changing the temperature affects temperature model migration, and the change made to bacteria is essential. Thus, changing the temperature equation has a significant influence on bacteria.

Water temperature is the most important factor in the growth and survival of bacteria because it can affect

Table 5 Summary of calibration and validation goodness-of-fit criteria in different studies

\begin{tabular}{|c|c|c|c|c|c|c|c|c|c|}
\hline & \multicolumn{3}{|c|}{ Upper Wakarusa watershed $^{\mathrm{a}}$} & \multicolumn{2}{|c|}{ Payne River watershed ${ }^{\mathrm{b}}$} & \multicolumn{2}{|c|}{ Shoal Creek watershed $^{\mathrm{c}}$} & \multicolumn{2}{|c|}{ James River basin $^{\mathrm{d}}$} \\
\hline & Rock Creek & Deer Creek & Auburn & Calibration & Validation & Calibration & Validation & Calibration & Validation \\
\hline$R^{2}$ & 0.42 & 0.41 & 0.36 & 0.002 & 0.030 & $\begin{array}{l}0.7 \text { (monthly) } \\
0.40 \text { (daily) }\end{array}$ & $\begin{array}{l}0.66 \text { (monthly) } \\
0.61 \text { (daily) }\end{array}$ & $0.00-0.09$ & $0.01-0.26$ \\
\hline$E_{\mathrm{NS}}$ & 0.20 & 0.31 & -2.20 & -0.154 & -0.192 & $\begin{array}{l}0.63 \text { (monthly) } \\
0.21 \text { (daily) }\end{array}$ & $\begin{array}{l}0.61 \text { (monthly) } \\
0.54 \text { (daily) }\end{array}$ & -6 to 0.03 & -0.08 to 0.21 \\
\hline$p_{\text {bias }}$ & - & - & - & $88.870 \%$ & $69.942 \%$ & - & - & -56 to $92 \%$ & 20 to $80 \%$ \\
\hline
\end{tabular}

${ }^{\mathrm{a}}$ Parajuli et al. (2009), ${ }^{\mathrm{b}}$ Frey et al. (2013), ${ }^{\mathrm{c}}$ Benham et al. (2006), ${ }^{\mathrm{d}}$ Baffaut and Benson (2009) 
bacterial enzymes. After the SWAT model was modified, seasonal changes (i.e., from winter to summer), the elevated level of water temperature is less than the original model; therefore, modeled enzymatic activity is decreased, and the death rate of fecal coliform was slowed down. The fecal coliform concentration in water increased; therefore, the values of parameters were altered.

As seen in the equation of bacteria equation in the SWAT model, water temperature plays an important role in the bacterial growth/death process. The THBACT $(0-10)$ parameter was designed to adjust the influence of water temperature in this equation. This parameter is a regulator in the equation and can adjust the water temperature values within a certain range. However, the results of this study indicate that there is a significant gap between Eqs. (1) and (6). The temperature regulating factor cannot completely erase this gap, which may lead to a large error during the adjustment process. As a result, it is necessary to modify the model produce a better simulation.

At present, the bacteria module of the SWAT model was modified; however, some researchers still think the SWAT simulation is limited in its ability to simulate bacteria. The studies of modified SWAT models mainly focus on two aspects: sediment release and radiation. However, many factors influence bacteria, including temperature, runoff, sediment and radiation. In this study, temperature factors were considered based on previous research. Combined with the results of other studies, this research can provide some reference for improving the simulation precision of SWAT.

\section{Parameter optimization of vegetative filter strips}

Research shows that DAFS ${ }_{\text {ratio }}$ and $\mathrm{DF}_{\text {con }}$ have a significant impact on bacteria removal efficiency. With the increase of $\mathrm{DAFS}_{\text {ratio }}$ and $\mathrm{DF}_{\text {con }}$, the removal efficiency may achieve lower values. DAFS ratio values from 5 to 200 and $\mathrm{DF}_{\text {con }}$ values from 0.2 to 0.8 were explored in nitrogen, phosphorus and sediment, and all results fit the general trend of reduced effectiveness at higher values (White and Arnold 2009). However, few studies address the impacts on bacteria levels. This study explored the impact of DAFS ratio $(20,50,80,120,150)$ and $\mathrm{DF}_{\text {con }}(0.25,0.4,0.6,0.75)$ on the removal of fecal coliform. The results are shown in Fig. 2. Similar conclusions can be drawn from Fig. 2 as from previous researchers' efforts (Cheng and Song 2009; White and Arnold 2009). There is a trend of reduced effectiveness at higher values of $\mathrm{DAFS}_{\text {ratio }}$ and $\mathrm{DF}_{\text {con }}$.

Many scholars have discussed vegetation buffer parameters. White and Arnold (2009) evaluated the effect of DAFS ${ }_{\text {ratio }}$ and $\mathrm{DF}_{\text {con }}$ on VFS effectiveness with different materials, which contained part. nitrogen, nitrate nitrogen, part. phosphorus, soluble phosphorus and sediment with $\mathrm{DAFS}_{\text {ratio }}$ values from 5 to 200 and $\mathrm{DF}_{\text {con }}$ values from 0.2 to 0.8 . The

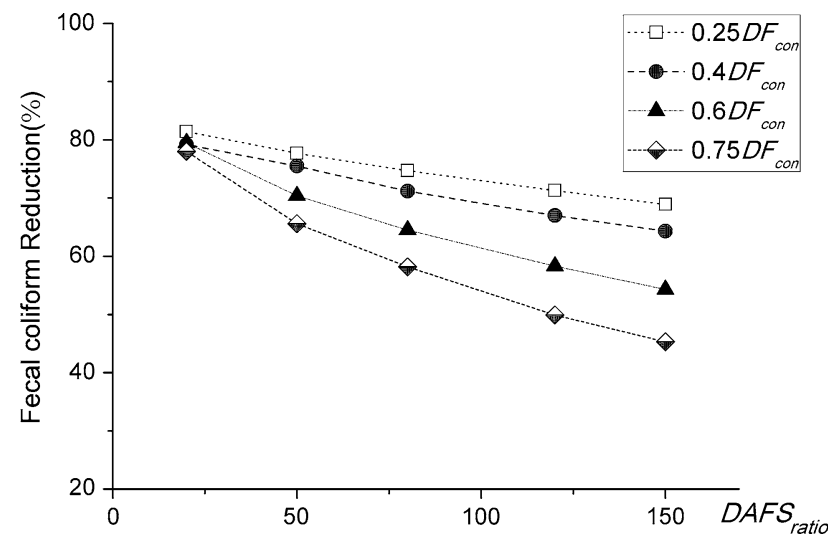

Fig. 2 Fecal coliform reduction in a vegetative filter strip

removal effect on different types of non-point source pollutants varies widely. In White and Arnold's research results, when DAFS ratio was 50 and $\mathrm{DF}_{\text {con }}$ was 0.6 , the reductions of part. nitrogen, nitrate nitrogen, part. phosphorus, soluble phosphorus, and sediment were approximately 50, 85, 60, 70 and $60 \%$, respectively. Cheng and Song (2009) summarized effective buffer area ratio (the ratio of buffer area to field runoff area) in relation to sediment trapping efficiency. When the ratio increased, sediment trapping efficiency also increased.

\section{Conclusion}

Water flow and fecal coliform samples in the Chao River watershed of the Miyun Reservoir were calibrated and validated based on a modified SWAT model. According to the VFS module of the SWAT model, fecal coliform removal efficiency was simulated using VFS parameters. The results show that the modified SWAT in the Chao River watershed can be the more aligned with actual conditions and has good applications for simulating fecal coliform. Based on similar studies, this study modified the temperature factors of the bacterial module in the SWAT model. Combining other research on bacterial model modifications makes the simulation more complete. In this study, through the simulation of two of the most important parameters in VFS, fecal coliform removal efficiency rules were identified that may provide the basis for the future research. The present research shows that VFS have positive effects on sediments, nutrients and bacteria; however, simulation studies on fate, transport and removal efficiency are fewer for pathogenic microorganisms. The removal of nutrients and sediment using VFS are given based on are a large number of experiments; however, due to a lack of measured data, the models of pesticides and bacteria are based on assumptions. This article hopes to provide suggestions for VFS simulations based on SWAT. The hope is that more research using long-term simulations and 
studying pathogenic microorganism removal methods can be performed in the agricultural watersheds. More reliable information of fecal contamination can be provided by the modified SWAT model. The results of fecal contamination and VFS can provide effective watershed management information for watershed management.

Acknowledgments The research was funded by National Natural Science Foundation of China (No. 51579011), National Science Foundation for Innovative Research Group (No. 51421065) and State Key Program of National Natural Science of China (No. 41530635).

\section{References}

Abbaspour KC (2011) SWAT-CUP4: SWAT calibration and uncertainty programs - a user manual. Department of Systems Analysis, Integrated Assessment and Modelling (SIAM), Eawag, Swiss Federal Institute of Aquatic Science and Technology, $\mathrm{CH}$, Switzerland

ASAE (2000) Standard D384.1 manure production and characteristics. American Society of Agricultural Engineers, St. Joseph

Baffaut C (2006) Little Sac River watershed fecal coliform total maximum daily load. FAPRI-UMC Report No. 11-06. Food and Agricultural Policy Research Institute, University of Missouri, Columbia

Baffaut C, Benson VW (2009) Modeling flow and pollutant transport in a karst watershed with SWAT. Trans ASAE 52(2):469-479

Baffaut C, Sadeghi A (2010) Bacteria modeling with SWAT for assessment and remediation studies: a review. Trans ASAE 53(5):1585-1594

Benham BL, Baffaut C, Zeckoski RW, Mankin KR, Pachepsky YA, Sadeghi AM, Brannan KM, Soupir ML, Habersack MJ (2006) Modeling bacteria fate and transport in watersheds to support TMDLS. Trans ASAE 49(4):987-1002

Bougeard M, Le Saux JC, Perenne N, Baffaut C, Robin M, Pommepuy M (2011) Modeling of Escherichia coli fluxes on a catchment and the impact on coastal water and shellfish quality. J Am Water Resour Assoc 47(2):350-366

Cardoso F, Shelton D, Sadeghi A, Shirmohammadi A, Pachepsky Y, Dulaney W (2012) Effectiveness of vegetated filter strips in retention of Escherichia coli and Salmonella from swine manure slurry. J Environ Manage 110:1-7

Cheng S, Song HT (2009) Conservation buffer systems for water quality security in South to North Water Transfer Project in China: an approach review. Front For China 4(4):394-401

Cho KH, Pachepsky YA, Kim JH, Kim JW, Park MH (2012) The modified SWAT model for predicting fecal coliforms in the Wachusett Reservoir Watershed, USA. Water Res 46:4750-4760

Coffey R, Cummins E, Flaherty VO, Cormican M (2010) Analysis of the soil and water assessment tool (SWAT) to model Cryptosporidium in surface water sources. Biosyst Eng 106:303-314

Entry JA, Hubbard RK, Thies JE, Fuhrmann JJ (2000) The influence of vegetation in riparian filterstrips on coliform bacteria: II. Survival in soils. J Environ Qual 29(4):1215-1224

Fox GA, Matlock EM, Guzman JA, Sahoo D, Stunkel KB (2011) Escherichia coli load reduction from runoff by vegetative filter strips: a laboratory-scale study. J Environ Qual 40(3):980-988

Frey SK, Topp E, Edge T, FallC GannonV, Jokinen C, Marti R, Neumann N, Ruecker N, Wilkes G, Lapen DR (2013) Using SWAT, bacteroidales microbial source tracking markers, and fecal indicator bacteria to predict waterborne pathogen occurrence in an agricultural watershed. Water Res 47:6326-6337
Hyer KE, Moyer DL (2003) Patterns and sources of fecal coliform bacteria in three streams in Virginia, 1999-2000. US Geological Survey, Water-Resources Investigations Report No. 03-4115. U.S. Geological Survey, Washington, DC

Kim JW, Pachepsky YA, Shelton DR, Coppock C (2010) Effect of streambed bacteria release on $E$. coli concentrations: monitoring and modeling with the modified SWAT. Ecol Model 221:1592-1604

Lewis DJ, Atwill ER, Lennox MS, Pereira MD, Miller WA, Conrad PA, Tate KW (2010) Management of microbial contamination in storm runoff from california coastal dairy pastures. J Environ Qual 39(5):1782-1789

Maringanti C, Chaubey I, Arabi M, Engel B (2008) A multi-objective optimization tool for the selection and placement of BMPs for pesticide control. Hydrol Earth Syst Sci Discuss 5:1821-1862

Middleton JH, Ambrose A (2005) Enumeration and antibiotic resistance patterns of fecal indicator organisms isolated from migratory Canada geese (Branta canadensis). J Wildl Dis 41(2):334-341

Moore JA, Smyth JD, Baker ES, Miner JR, Moffitt DC (1989) Modeling bacteria movement in livestock manure systems. Trans ASAE 32(3):1049-1053

Moyer DL, Hyer KE (2003) Use of the hydrological simulation program-FORTRAN and bacterial source tracking for development of the fecal coliform total maximum daily load (TMDL) for Christians Creek, Augusta County, Virginia. Water-Resources Investigations Report No. 03-4162. U.S. Geological Survey, Washington, DC

Parajuli PB, Mankin KR, Barnes PL (2007) New methods in modeling source-specific bacteria at watershed scale using SWAT. In: Proceedings of the watershed management to meet water quality standards and total maximum daily load (TMDLs). ASABE Publication No. 701P0207. ASABE, St. Joseph

Parajuli PB, Mankin KR, Barnes PL (2008) Applicability of targeting vegetative filter strips to abate fecal bacteria and sediment yield using SWAT. Agric Water Manage 95:1189-1200

Parajuli PB, Mankin KR, Barnes LP (2009) Source specific fecal bacteria modeling using soil and water assessment tool model. Bioresour Technol 100:953-963

Pilgrim JM, Fang X, Stefan HG (1998) Stream temperature cortelations with air temperatures in Minnesota: implications for climate warming. J Am Water Resour Assoc 34(5):1109-1121

Shen Z, Chen L, Xu L (2013) A topography analysis incorporated optimization method for the selection and placement of best management practices. Plos One 8(1):e54520. doi:10.1371/ journal.pone.0054520

Shen ZY, Qiu JL, Hong Q, Chen L (2014) Simulation of spatial and temporal distributions of non-point source pollution load in the Three Gorges Reservoir Region. Sci Total Environ 493:138-146

Stefan HG, Preud'Homme EB (1993) Stream temperature estimation from air temperature. J Am Water Resour Assoc 29(1):27-45

Wang SF, Wang XK, Ouyang ZY (2012) Effects of land use, climate, topography and soil properties on regional soil organic carbon and total nitrogen in the upstream watershed of Miyun Reservoir, North China. J Environ Sci 24(3):387-395

White MJ, Arnold JG (2009) Development of a simplistic vegetative filter strip model for sediment and nutrient retention at the field scale. Hydrol Process 23:1602-1616

WHO/UNICEF (2000) Global water supply and sanitation assessment 2000 report (online). World Health Organization and United Nations Children's Fund, New York

Yang Q, Tam NFY, Wong YS, Luan TG, Su WS, Lan CY et al (2008) Potential use of mangroves as constructed wetland for municipal sewage treatment in Futian, Shenzhen, China. Mar Pollut Bull 57:735-743

Zheng CC, Zhou LX (2013) Antibacterial potency of housefly larvae extract from sewage sludge through bioconversion. J Environ Sci 25(9):1897-1905 